\title{
Histochemical Screening of Leaves Compared to in situ and in vitro Calluses of Solanum aculeatissimum Jacq.
}

\author{
Luciana Arantes Dantas ${ }^{1}$, Anielly Monteiro Melo ${ }^{1}$, Paulo Sérgio Pereira ${ }^{1}$, Lucas Anjos Souza ${ }^{1}$, \\ Sebastião Carvalho Vasconcelos Filho ${ }^{1} \&$ Fabiano Guimarães Silva ${ }^{1}$ \\ ${ }^{1}$ Instituto Federal Goiano, Campus Rio Verde, Brazil \\ Correspondence: Fabiano Guimarães Silva, Instituto Federal Goiano, Campus Rio Verde, Brazil. E-mail: \\ fabianoifgoiano@gmail.com
}

Received: April 6, 2017

doi:10.5539/jas.v9n7p80
Accepted: May 22, $2017 \quad$ Online Published: June 15, 2017

URL: https://doi.org/10.5539/jas.v9n7p80

\begin{abstract}
Solanum aculeatissimum Jacq. is a shrub considered to have valuable medicinal potential in folk medicine in China and Nepal. The fruit extract is used for toothache, scabies, headache, dandruff and lice infestation. A limited number of reports address techniques of tissue culture for this plant. Therefore, the objective of the present study was to establish the species in vitro from seeds and subsequently to compare the production of primary and secondary metabolites in the plant's leaves in situ and in vitro and in calluses obtained from leaf segments. Seedlings were established from seeds in Murashige and Skoog (MS) medium with a 50\% salt concentration. The seedlings were kept under a photoperiod of $16 \mathrm{~h}$ of photosynthetically active radiation at $45-55 \mu \mathrm{mol} \mathrm{m} \mathrm{m}^{-2} \mathrm{~s}^{-1}$ provided by fluorescent bulbs. The callus induction experiment followed a completely randomized design consisting of 2 doses of kinetin (KIN), 2.5 and $10 \mathrm{mg} \mathrm{L}^{-1}$, in the absence or presence of light. Segments were inoculated in glass bottles containing $50 \%$ MS medium, $30 \mathrm{~g} \mathrm{~L}^{-1}$ of sucrose, $3.5 \mathrm{~g} \mathrm{~L}^{-1}$ of agar and $1 \mathrm{mg} \mathrm{L}^{-1}$ of 2,4-D (2,4-dichlorophenoxyacetic acid), with the $\mathrm{pH}$ adjusted to $5.7 \pm 0.03$. We observed that in vitro cultivation of calluses resulted in greater secondary metabolite production and accumulation, regardless of KIN concentration. In calluses, the best alternative for potentiation occurred in cultivation in the absence of light when compared to the tissues of both in situ and in vitro leaves.
\end{abstract}

Keywords: elicitation, flavonoids, phenolic compounds, secondary metabolite, terpenes, tissue culture

\section{Introduction}

The genus Solanum is the largest and most complex genus in the family Solanaceae, with approximately 1,500 species inhabiting tropical and subtropical regions of the world and South America, which is the center of its diversity and distribution. Ghimire et al. (2012) describe that Solanum aculeatissimum Jacq. has valuable medicinal potential and is largely used in folk medicine in India and Nepal; its fruit extracts are used for toothache, scabies, headache, dandruff and lice infestation. Nabeta (1993) states that this specie is native to tropical America and is widely used in China for the treatment of bronchitis and rheumatism. Thus, considering the medicinal value attributed to $S$. aculeatissimum, Nabeta reported that bioactive compounds such as alkaloids and steroidal saponins, considered useful sources of pregnan derivatives, have been isolated from the stems, leaves, roots and fruits of this plant.

Indigenous plant species have great potential in the development of drugs and pharmaceutical raw materials, thus drawing great interest in the global economic market. Brazil stands out for possessing a huge genetic variety of plants. Even if a small portion of the available plant species is studied, both in Brazil and worldwide, the possibilities of the development of bioactives existing in the immense plant variety throughout the world are remarkable (Rossato et al., 2012).

Some plant species produce chemical compounds of economic interest for the development of new products. Biotechnology has been at the forefront in many sectors, such as in the pharmaceutical industry, with the search for alternatives and sources of new drugs and fragrances of natural origin; in the food industry, in the supply of flavoring and coloring; and in the agricultural sector, in the search for natural fungicides and insecticides. With the evolution of biotechnology, the provision of useful information on the application of active metabolites present in plant species is characterized as a tool that stands out in many areas of scientific and technological knowledge worldwide (Anselmo \& Lima, 2014; Santos et al., 2012). 
Therefore, the use of biotechnology in the cultivation of plant cells can be an alternative for increasing the output of bioactive compounds through the study of plant biosynthetic pathways, which in turn can support studies in gathering relevant data for improving phytochemical production. Oliveira et al. (2009) emphasized the cultivation of cells and plant tissues as a research alternative in the production of several secondary metabolites in seedlings and calluses. Yendo et al. (2010) and Karuppusamy (2009) assert that some strategies have been used for improving the production of metabolites in cultures based on the principle of increasing the yield of the metabolite of interest. Hussain et al. (2012) report that the use of calluses has great potential in the production of a variety of secondary metabolites because the production becomes more reliable, simple and predictable.

Light is an important environmental factor in regulating various processes of growth and development in plants and consequently their tissues. Therefore, it may be a strategy to be used in the production of callus metabolites of interest. The multiple hormone pathways are mediated and altered by light and these endogenous auxin and cytokine levels influence the signaling of metabolic pathways of photomorphogenesis regulation by phytochromes (Lau \& Deng, 2010; Franklin \& Quail, 2010).

The production of data on leaf histochemistry is of great importance for the quality control of raw materials in the production of phytotherapeutic agents (Adams et al., 2013; Andrade et al., 2017; Santos et al., 2013). Based on histological data, new species with pharmacological potential can be studied as to the chemical nature of their cellular compounds (Oliveira et al., 2015; Vasconcelos et al., 2013). According to Martins and Appezzato-da-Glória (2006), correct histochemical characterization and identification ensure confidence in the use the plants for therapeutic purposes and in complimentary chemical studies. Araújo et al. (2010) and Picoli et al. (2013) cite that histochemical studies in Solanum are not much explored.

Preliminary pharmacognostic data assist in the description of anatomical and histochemical characteristics of the species studied, provides phytochemical information of plants with medicinal potential. Thus, the objective of the present study was to identify and locate primary and secondary metabolites in leaf tissues of $S$. aculeatissimum Jacq. cultivated in situ, in vitro and in callus obtained from leaf explants, verifying the effect of lightness and doses of kinetin on in vitro histochemical response compared to in situ leaves.

\section{Materials and Methods}

\section{1 in situ Plant Material}

The experiment was conducted in the Laboratory of Plant Tissue Culture and in the Laboratory of Plant Anatomy of the Goiano Federal Institute (Instituto Federal Goiano - IF Goiano), Campus Rio Verde, Goiás State (GO), Brazil. The voucher specimen is deposited in the IF Goiano Herbarium under record number 496. For in situ experiments, leaves with 40 days were harvested at coordinates $17^{\circ} 48^{\prime} 343^{\prime \prime} \mathrm{S}-50^{\circ} 54^{\prime} 005^{\prime \prime} \mathrm{W}, 616 \mathrm{~m}$ altitude.

\section{2 in vitro Establishment}

For the in vitro establishment of seedlings, MS medium (Murashige \& Skoog, 1962) with a 50\% salt concentration, $30 \mathrm{~g} \mathrm{~L}^{-1}$ sucrose, $3.5 \mathrm{~g} \mathrm{~L}^{-1}$ agar (Dinâmica ${ }^{\circledR}$ ) and a pH adjusted to $5.7 \pm 0.03$ was used. A total of 10 $\mathrm{mL}$ of medium was added to each test tube $(25 \times 150 \mathrm{~mm})$. The tubes were then sealed with a polypropylene plastic cap and autoclaved at $121{ }^{\circ} \mathrm{C}$ under a pressure of $1.05 \mathrm{~kg} \mathrm{~cm}^{-2}$ for 20 minutes. After autoclaving, the tubes were kept in a growth room, at a temperature of $25 \pm 3{ }^{\circ} \mathrm{C}$ and a relative humidity of $45 \%$ until the in vitro inoculation of the seeds.

Prior to the inoculation, the seeds were disinfected by wrapping them with gauze and immersing them under running water for 30 minutes, followed by immersion in $70 \%$ ethanol for 1 minute and then immersion in sodium hypochlorite $(\mathrm{NaClO})$ solution (commercial bleach $-2.5 \%$ of active chlorine) containing $0.02 \%$ of polysorbate (Tween) for 15 minutes. Subsequently, under laminar flow, the seeds were washed 3 times in distilled and autoclaved water to eliminate the residues of the disinfecting solutions and were then inoculated in vitro.

The seedlings produced were transferred each 30 days to a new medium, identical to the medium used for seed germination. After germination, seedlings were kept under a 16-h photoperiod of photo synthetically active radiation at $45-55 \mu \mathrm{mol} \mathrm{m} \mathrm{m}^{-2} \mathrm{~s}^{-1}$, provided by fluorescent bulbs. Leaves used for in vitro experiment were also harvested with 40 days, similarly as the leaves harvested for in situ.

\subsection{Induction of Calluses in Solanum aculeatissimum Jacq.}

A completely randomized experiment was designed for the induction of calluses, consisting of a $2 \times 2$ factorial scheme with 2 exposure conditions (light and dark) $\times 2$ kinetin $(\mathrm{KIN})$ concentrations $\left(2.5\right.$ and $\left.10 \mathrm{mg} \mathrm{L}^{-1}\right)$. Therefore, for each treatment, $41-\mathrm{cm}^{2}$ leaf segments nearly with 40 days derived from the material established in 
vitro were inoculated in bottles containing $40 \mathrm{~mL}$ of $50 \% \mathrm{MS}, 30 \mathrm{~g} \mathrm{~L}^{-1}$ of sucrose, $3.5 \mathrm{~g} \mathrm{~L}^{-1}$ of agar and $1 \mathrm{mg} \mathrm{L}^{-1}$ of 2,4-D (2,4-dichlorophenoxyacetic acid) with the $\mathrm{pH}$ adjusted to $5.7 \pm 0.03$. After 30 days, calluses were induced and kept in a growth room under the same conditions described in the in vitro establishment.

\subsection{Histochemistry}

The histochemical tests were conducted to detect compounds belonging to the primary and secondary metabolism of leaves with 40 days both in vitro and in situ and calluses of S. aculeatissimum Jacq. Fresh leaves were cut at main vein region and calluses were sectioned manually using a disposable razor. Leaves measuring approximately $8 \mathrm{~cm}$ collected in the field were compared to leaves cultivated in vitro and with the calluses obtained.

For the identification of primary metabolic compounds, the following reagents were used: Sudan III reagent for detecting lipids (Orange coloring) (Johansen, 1940), Xylidine Ponceau (XP) (Orange red) for total proteins (O’Brien \& McCully, 1981) and Periodic acid/Schiff stain (PAS) for general polysaccharides (Magenta) (Maia, 1979). For the identification of secondary metabolic compounds, potassium dichromate was used to detect general phenolic compounds (Reddish-Brown) (Gabe, 1968), aluminum chloridewas used as a fluorochrome for flavonoids (Fluorescence) under ultraviolet (UV) light, Nadi reagent was used for identifying terpenes (Blue) (essential oils) (David \& Carde, 1964), and Wagner reagent was used for identifying nitrogenous compounds as alkaloids (Dark brown) (Furr \& Mahlberg, 1981).

Based on the score used by Matias et al. (2016), the classes of the compounds investigated were qualitatively measured, being (0) for absence, (1) moderate presence, (2) pronounced presence.

Photomicrographs were taken under an Olympus BX61optical microscope using an Olympus DP73 camera and the U-photo system.

\section{Results}

\subsection{Carbohydrates, Lipids and Proteins}

In all samples of in vitro and in situ leaves and in calluses, the PAS reaction produced a magenta color (Figure 1: A and B), highlighting the presence of polysaccharides in the cell wall and in glandular trichomes with secretory heads. In addition to the color, evidencing the carbohydrates present in the calluses (Figure 1: C-F), the presence of starch granules in all cultivated calluses was also observed. 

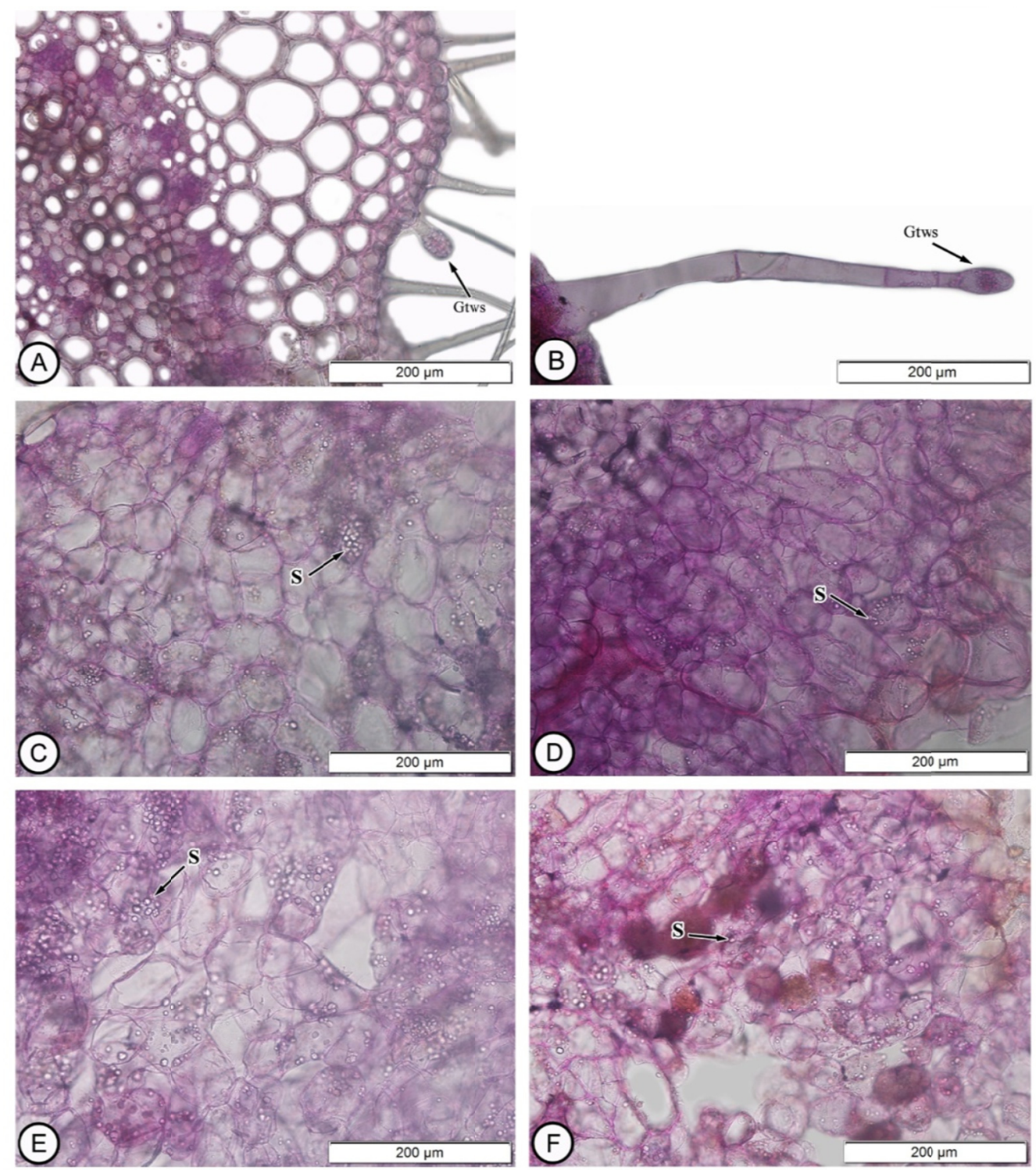

Figure 1. Cross-sections of S. aculeatissimum Jacq. leaves collected in situ (A) and cultivated in vitro in MS medium with 50\% salts (B); and calluses grown under light (C and E) and in the dark (D and F), both with 2.5 $\mathrm{mg} \mathrm{L}^{-1} \mathrm{KIN}$ and $10 \mathrm{mg} \mathrm{L}^{-1} \mathrm{KIN}$, respectively, and subjected to PAS staining for carbohydrate detection. Gtws: Glandular trichome with secretory head; S: Starch

None of the treatment showed protein accumulation because it does not presents orange red. Carbohydrates and lipids were detected in all samples were only found in calluses.

In leaves, lipids were found in a very thin region of leaf cuticle (Figure 2: A and B). As for the calluses grown in both, in the light (Figure 2: $\mathrm{C}$ and $\mathrm{E}$ ) and in the dark (Figure 2: D and F), the presence of disorganized lipids was found in most cells; however, in some regions of the dark-cultivated calluses, an intense color was observed on the surface of the callus. As for proteins, the XP test was negative with all analyzed material (Figure 3). 

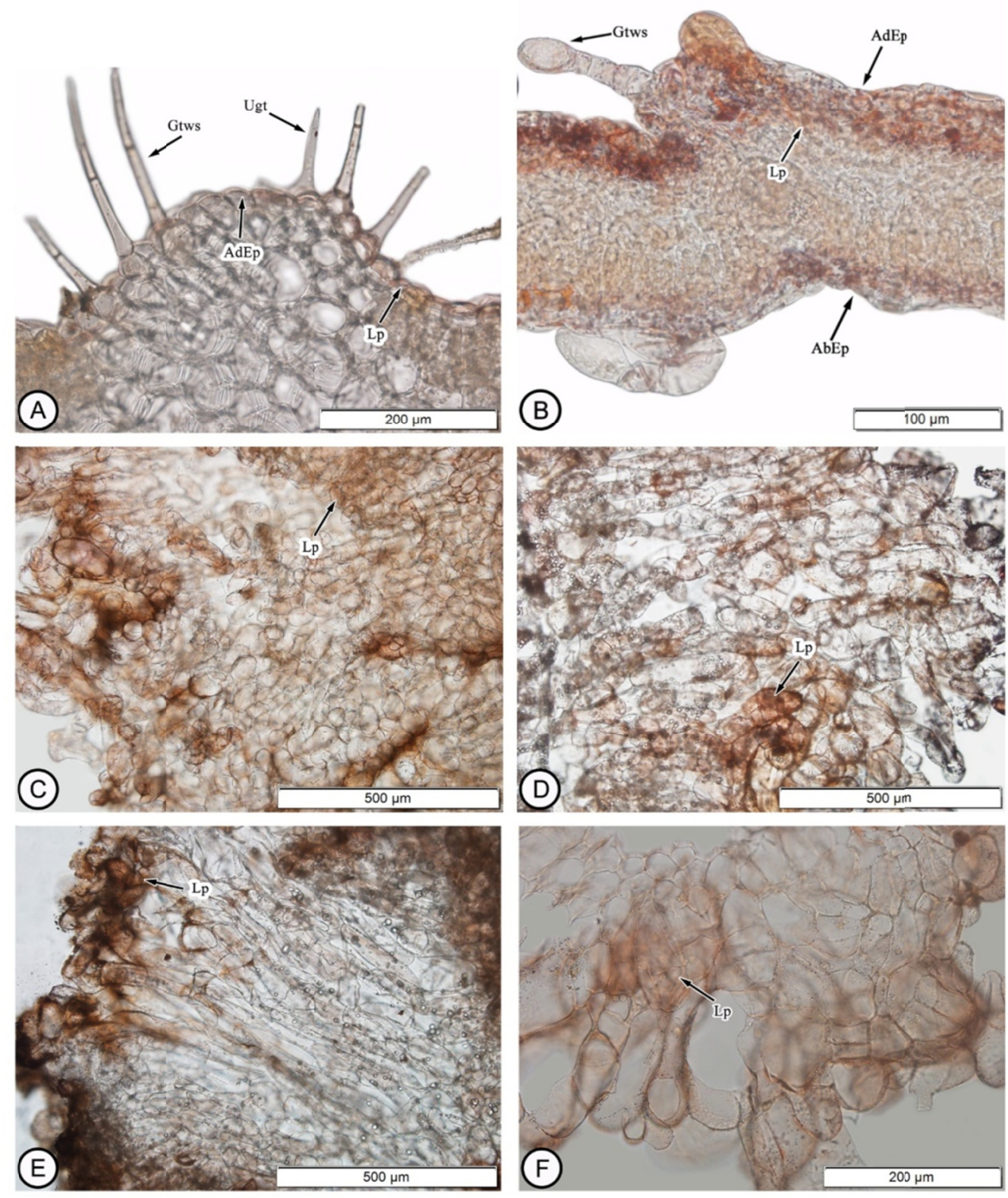

Figure 2. Cross-sections of $S$. aculeatissimum Jacq. leaves collected in situ (A) and cultivated in vitro in MS medium with 50\% salts (B); and calluses grown under light (C and E) and in the dark (D and F), both with 2.5 $\mathrm{mg} \mathrm{L}^{-1} \mathrm{KIN}$ and $10 \mathrm{mg} \mathrm{L}^{-1} \mathrm{KIN}$, respectively, and subjected to Sudan III staining for lipid detection. Mft: Multicellular filiform trichome; Ugt: Unicellular glandular trichome; Gtws: Glandular trichome with secretory head; AdEp: Adaxial epidermis; AbEp: Abaxial epidermis; Lp: Lipids 


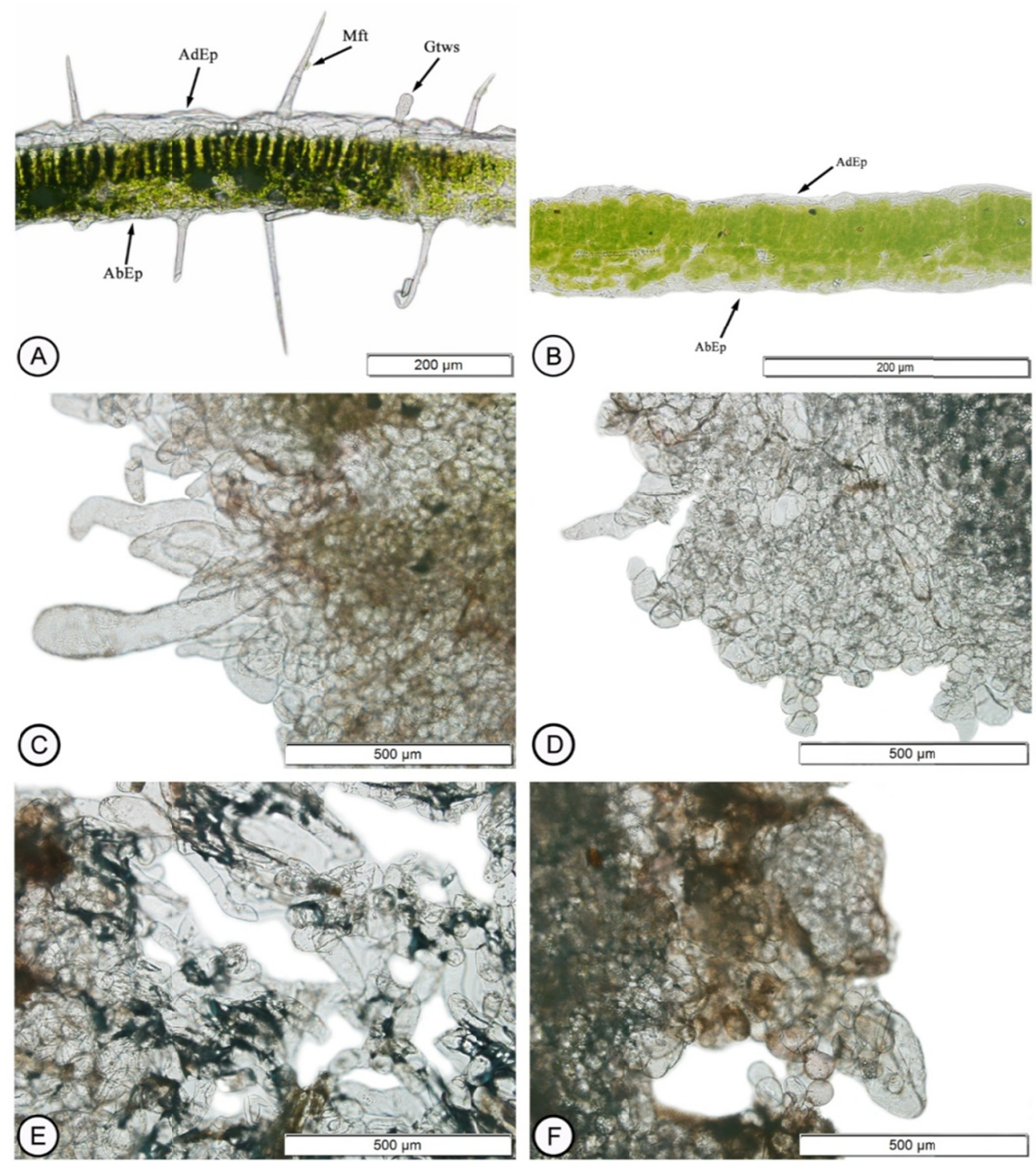

Figure 3. Cross-sections of S. aculeatissimum Jacq. leaves collected in situ (A) and cultivated in vitro in MS medium with 50\% salts (B); and calluses grown under light (C and E) and in the dark (D and F), both with 2.5 $\mathrm{mg} \mathrm{L}^{-1} \mathrm{KIN}$ and $10 \mathrm{mg} \mathrm{L}^{-1} \mathrm{KIN}$, respectively, and subjected to Xylidine Ponceau (XP) absence of color staining orange red for protein detection. Mft: Multicellular filiform trichome; Gtws: Glandular trichome with secretory head; AdEp: Adaxial epidermis; AbEp: Abaxial epidermis

\subsection{Secondary Compounds}

According to observations of in situ leaf sections, it was possible to identify the presence of terpenes in filiform and glandular trichomes with unicellular secretory heads and in the entire leaf cuticle extension. In in vitro cultivated leaves, terpenes were only detected in the secretory heads of some glandular trichomes (Figure 4). In calluses, the production of terpenoid compounds was evident in all treatments, except for calluses grown under light with $2.5 \mathrm{mg} \mathrm{L}^{-1} \mathrm{KIN}$ concentration. 

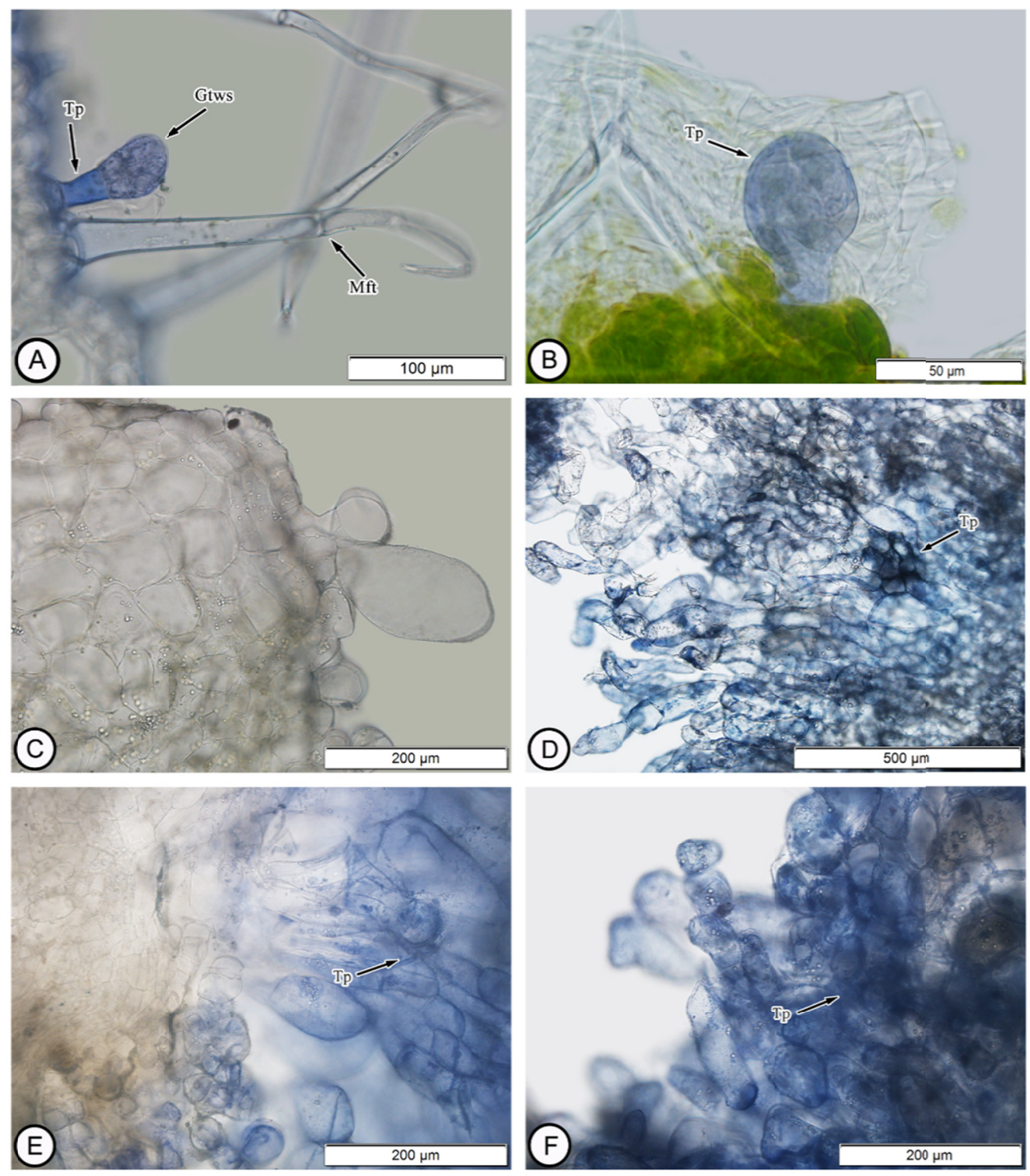

Figure 4. Cross-sections of $S$. aculeatissimum Jacq. leaves collected in situ (A) and cultivated in vitro in MS medium with $50 \%$ salts (B); and calluses grown under light (C and E) and in the dark (D and F), both with 2.5 $\mathrm{mg} \mathrm{L}^{-1} \mathrm{KIN}$ and $10 \mathrm{mg} \mathrm{L}^{-1} \mathrm{KIN}$, respectively, and subjected to NADI staining for terpenoid detection. Mft: Multicellular filiform trichome; Gtws: Glandular trichome with secretory head; Tp: Terpenic compounds

Phenolic compounds were detected along the entire length of the in situ leaf, both with and without use of potassium dichromate reagent (Figure 5: A and B), and also when the material was exposed to UV radiation (Figure 5: C-E), as observed by the emission of greenish-yellow autofluorescence. However, in the in vitro cultivated leaves, these compounds were observed less frequently.

In calluses, phenolic compounds were found in large numbers in treatments cultivated with $10 \mathrm{mg} \mathrm{L}^{-1} \mathrm{KIN}$ (Figure 5: I and J), both grown under light and in the dark. Regarding the $2.5 \mathrm{mg} \mathrm{L}^{-1} \mathrm{KIN}$ concentration, small amounts of phenolic compounds were detected compared to the other treatments (Figure 5: H). In all observations, the dark-grown calluses showed a higher occurrence of phenolic compounds. 

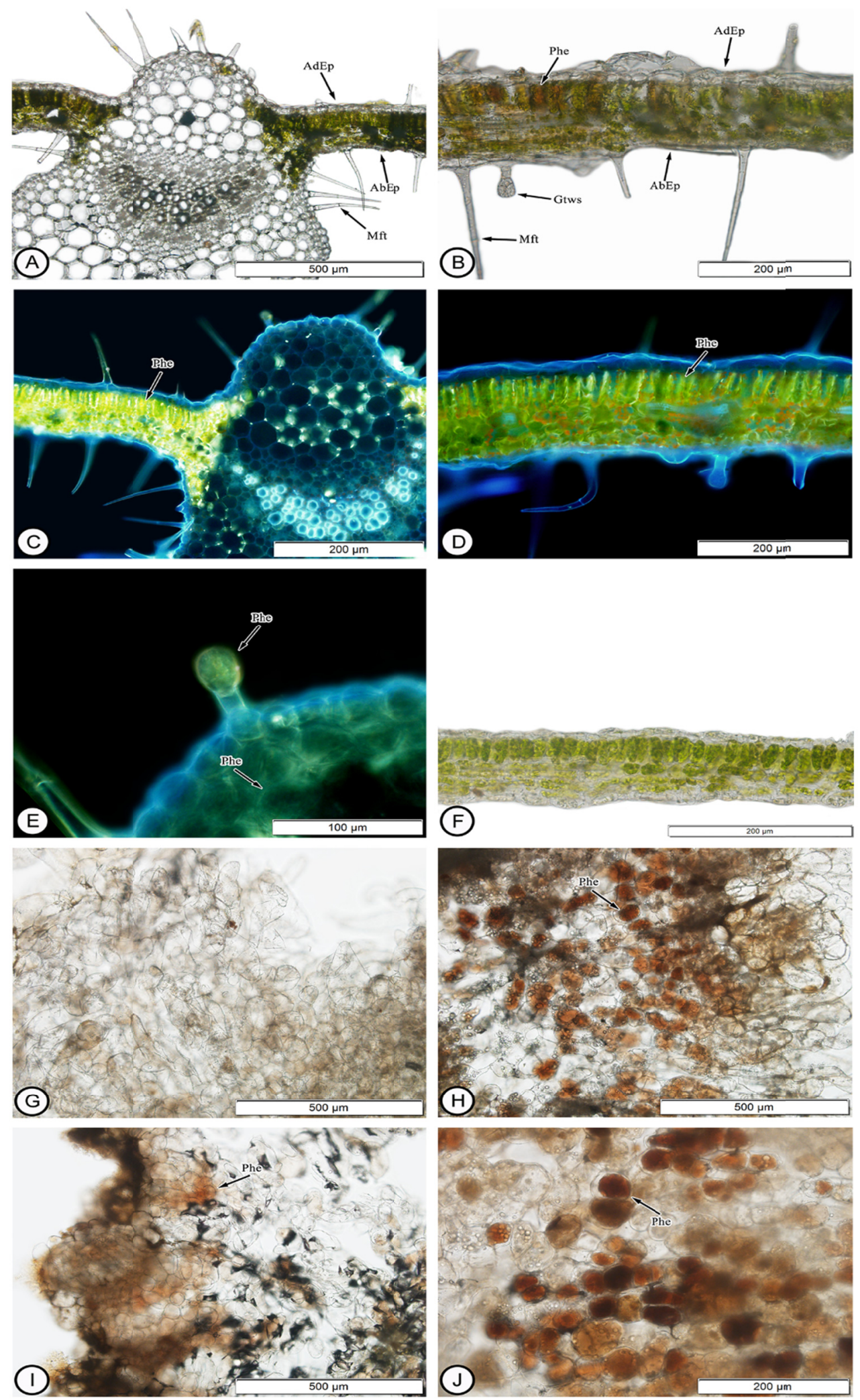

Figure 5. Cross-sections of S. aculeatissimum Jacq. in situ leaves after staining for phenolic compounds (A and B) and autofluorescence (C, D and E) following subjection to UV radiation; leaves were cultivated in vitro in MS medium with $50 \%$ salts $(\mathrm{B})$; calluses grown under light $(\mathrm{G}$ and $\mathrm{I})$ and in the dark ( $\mathrm{H}$ and $\mathrm{J}$ ), both with $2.5 \mathrm{mg} \mathrm{L}^{-1}$ $\mathrm{KIN}$ and $10 \mathrm{mg} \mathrm{L}^{-1} \mathrm{KIN}$, respectively. With the exception of C, D and $\mathrm{E}$, the remaining material was subjected to potassium dichromate staining. Mft: Multicellular filiform trichome; Gtws: Glandular trichome with secretory head; Phe: Phenolic compounds; AdEp: Adaxial epidermis; AbEp: Abaxial epidermis 
Calluses grown with $10 \mathrm{mg} \mathrm{L}^{-1} \mathrm{KIN}$ regardless of light condition showed no difference in detection of polysaccharides, lipids or nitrogen compounds (alkaloids). For calluses grown with $2.5 \mathrm{mg} \mathrm{L}^{-1} \mathrm{KIN}$, there were differences in the detection of terpenes, phenolic compounds and flavonoids in callus grown under light and in the dark.

Complementing the phenolic compounds class, the fluorochrome aluminum chloride was used to detect the presence of flavonoids, which, in general, emit a secondary greenish-yellow fluorescence, as observed in the filiform and glandular trichomes with secretory headsin both in situ and in vitro leaves (Figure 6). Fluorescence was detected in all calluses tested; however, in calluses cultivated with $10 \mathrm{mg} \mathrm{L}^{-1} \mathrm{KIN}$, large concentrations of flavonoids were observed, especially in those grown in the dark (Figure 6: G and $\mathrm{H}$ ). The presence of stellate trichomes was detectedin S. aculeatissimum (Figure 7: A and B). 

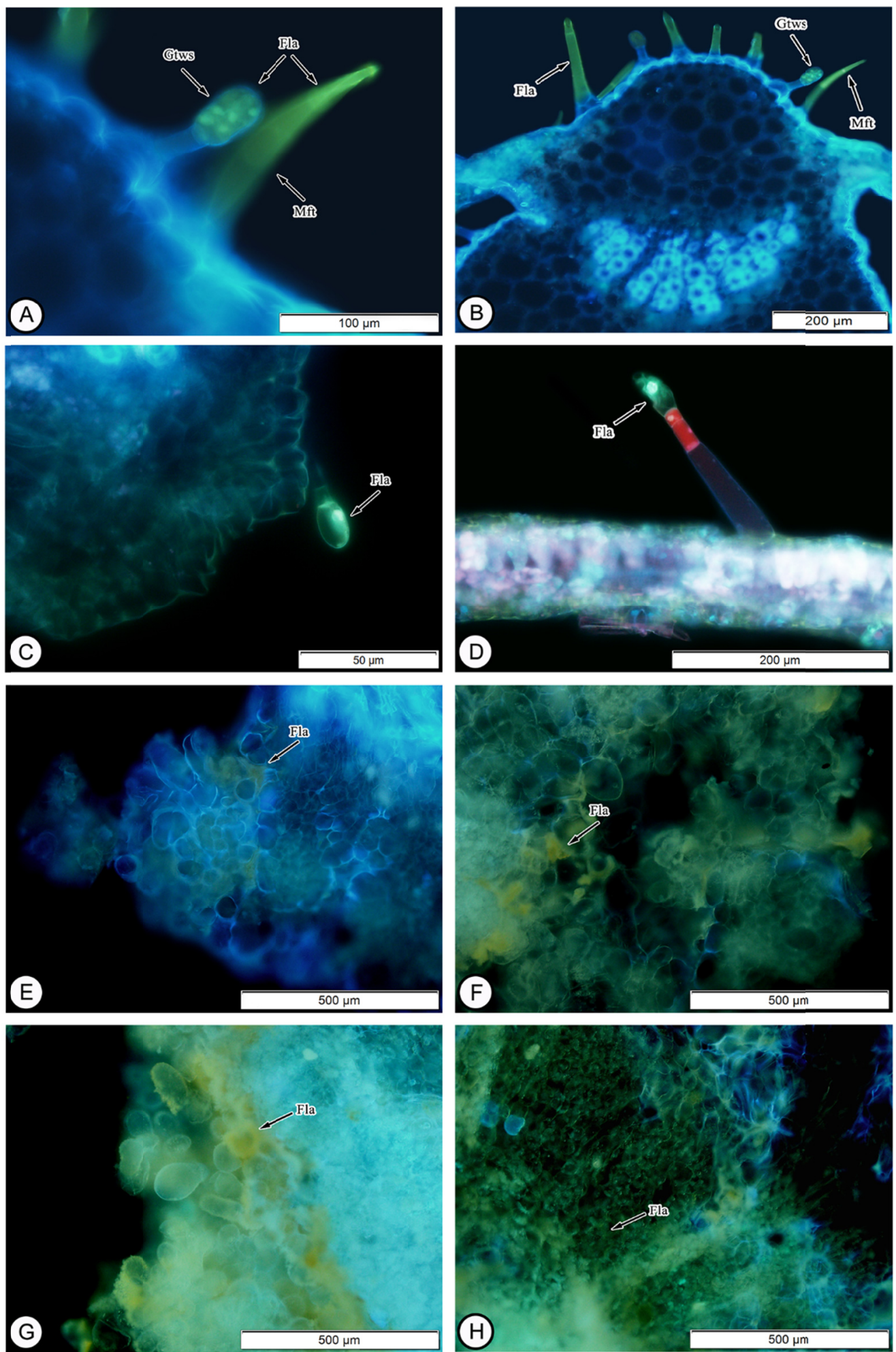

Figure 6. Cross-sections of $S$. aculeatissimum Jacq. leaves collected in situ (A and B) and cultivated in vitro in MS medium with 50\% salts (C and D); calluses grown under light (E and $G$ ) and in the dark $(F$ and $H)$, both with $2.5 \mathrm{mg} \mathrm{L}^{-1} \mathrm{KIN}$ and $10 \mathrm{mg} \mathrm{L}^{-1} \mathrm{KIN}$, respectively, and subjected to the fluorochrome aluminum chloride for flavonoid detection. Mft: Multicellular filiform trichome; Gtws: Glandular trichome with secretory head; Fla: Flavonoids. 


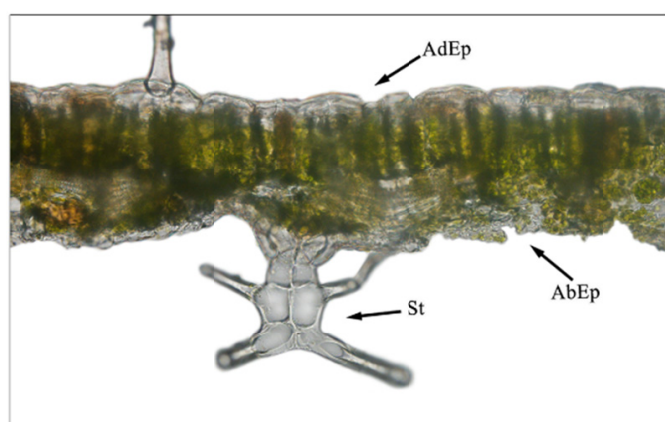

(A)

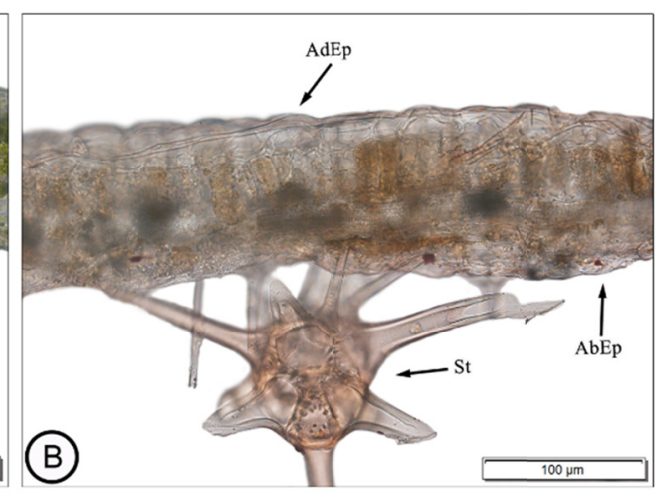

Figure 7. Cross-section of S. aculeatissimum Jacq. leaves collected in situ, showing the presence of stellate trichomes (A-B). AdEp: Adaxial epidermis; AbEp: Abaxial epidermis; St: Stellate trichomes

In the identification of nitrogenous residues, the alkaloids stain reddish brown and due to the presence of iodine in the reagent, starch is evidenced in dark blue. Alkaloids were detected in all the cores tested (Figure 8: C-F). Overall, the detection tests for the major metabolite classes revealed variations in both primary and secondary metabolic compounds (Table 1). 

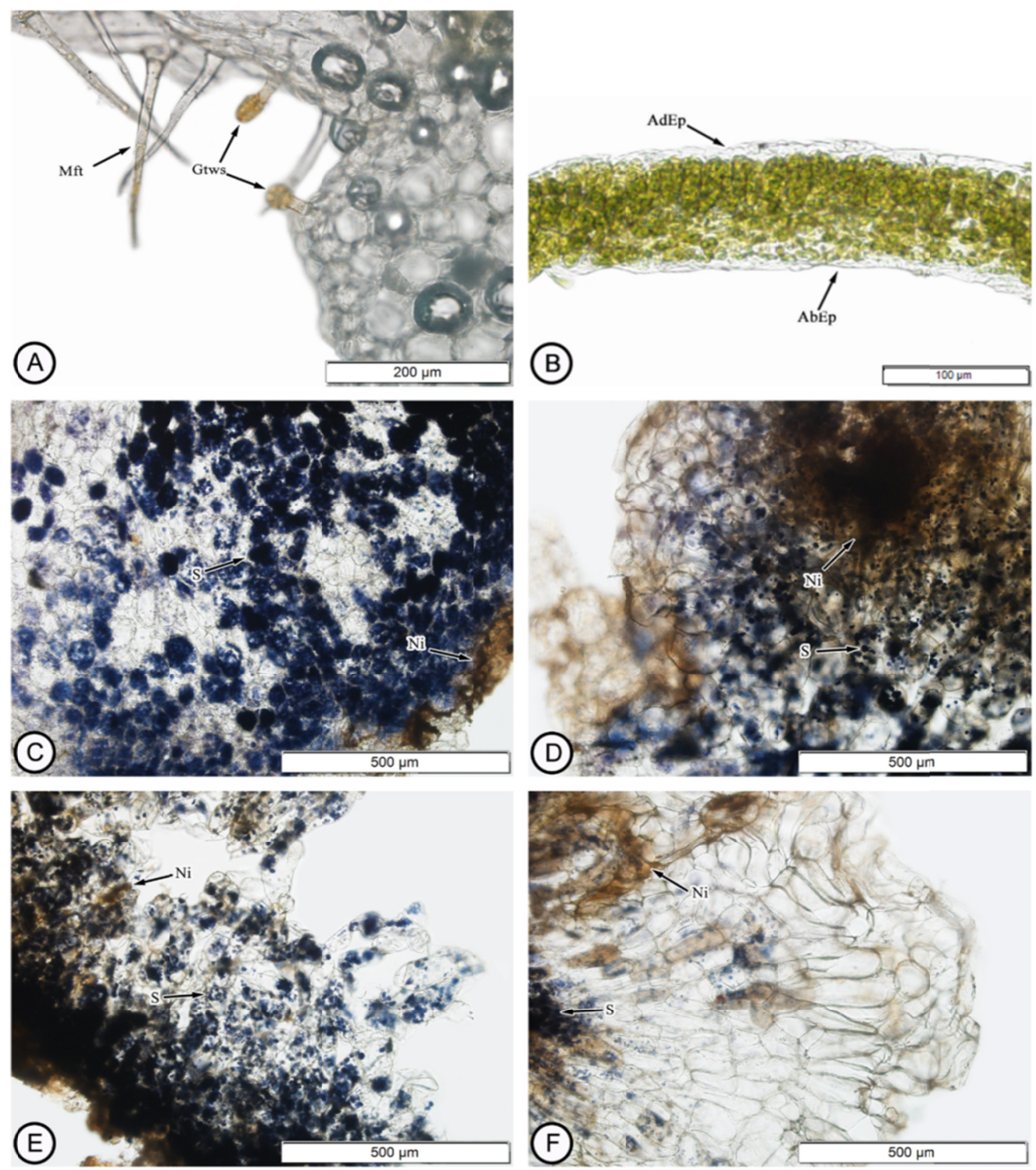

Figure 8. Cross-sections of $S$. aculeatissimum Jacq. leaves collected in situ (A) and cultivated in vitro in MS medium with $50 \%$ salts (B); calluses grown under light (C and E) and in the dark (D and F), both with $2.5 \mathrm{mg} \mathrm{L}^{-1}$ $\mathrm{KIN}$ and $10 \mathrm{mg} \mathrm{L}^{-1} \mathrm{KIN}$, respectively, and subjected to the Wagner's reagent test for nitrogenous compound detection. Mft: Multicellular filiform trichome; Gtws: Glandular trichome with secretory head; AdEp: Adaxial epidermis; AbEp: Abaxial epidermis, S: Starch; Ni: Nitrogenous compounds (alkaloids) 
Table 1. Histochemical test results in leaves of S. aculeatissimum Jacq. collected in situ and established in vitro and in calluses with different doses of KIN (A: $2.5 \mathrm{mg} \mathrm{L}^{-1}$; B: $10 \mathrm{mg} \mathrm{L}^{-1}$ ) for detecting the major classes of metabolites

\begin{tabular}{|c|c|c|c|c|c|c|}
\hline & \multirow{2}{*}{ in situ leaf } & \multirow{2}{*}{ in vitro leaf } & \multicolumn{2}{|c|}{ Callus A } & \multicolumn{2}{|c|}{ Callus B } \\
\hline & & & Light & Dark & Light & Dark \\
\hline \multicolumn{7}{|l|}{ Primary Metabolite } \\
\hline Carbohydrates & 1 & 1 & 1 & 1 & 2 & 2 \\
\hline Lipids & 1 & 1 & 1 & 1 & 1 & 1 \\
\hline Proteins & 0 & 0 & 0 & 0 & 0 & 0 \\
\hline \multicolumn{7}{|l|}{ Secondary Metabolite } \\
\hline Terpenes & 1 & 1 & 0 & 2 & 1 & 2 \\
\hline Total phenols & 1 & 1 & 1 & 2 & 1 & 2 \\
\hline Flavonoids & 1 & 1 & 1 & 2 & 1 & 2 \\
\hline Nitrogenous (alkaloids) & 0 & 0 & 1 & 1 & 1 & 1 \\
\hline
\end{tabular}

Note. 0 (absente); 1 (moderate); 2 (pronouced).

\section{Discussion}

The presence of polysaccharides detected in the cell wall and the secretory head gland trichomes (Figure 1) observed in this experiment with $S$. aculeatissimum was similar in the bioassays performed with callus of Gracilariopsis tenuifrons (CJ Bird and EC Oliveira) Frederiq and Hommers A slightly positive reaction, indicating the presence of cellulosic material in cell walls (Bouzon et al., 2011).

In the calluses, the presence of carbohydrates was observed due to the magenta color and the presence of starch granules in all cultivated calluses. Nogueira et al. (2007) reported that the abundant occurrence of starch granules, such as found in $S$. aculeatissimum, is associated with the embryogenic potential in calluses of small murici (Byrsonima intermedia A. Juss.) because this metabolite is the source of intense energy during cell division and of high respiratory rates for subsequent embryo development.

In both, in vitro and in situ leaves, lipids were detected in the thin leaf cuticle region. This finding is related to the basic survival function of the plant and to its hydrophobic characteristics, which allows water loss to beavoided on the surface of the epidermis. The cuticle provides an efficient barrier against most pathogens, along with the chemical barriers on the plant's surface. For example, in a study of the $C w p 1$ cuticle gene in mutant tomatoes, the fruits underwent modification in the composition and thickness of the cuticle, becoming more resistant to the fungus Botrytis cinerea (Reina-Pinto \& Yephremov, 2009). In calluses, grown under both, light and dark conditions, a more intense presence of disorganized lipids was observed in the most superficial region, demonstrating the protection capacity of the entire callus surface; however, in dark-grown calluses, the presence of lipids was more intense.

An absence of color orange red indicating the presence of protein accumulation was detected in any of the material analyzed. A similar result was found in leaves of Solanum granuloso (de Toledo et al., 2013).

According toda Silva et al. (2003), in the family Solanaceae, free flavonoids are found in the aerial parts of the genus Solanum; specifically in Solanum paludosum Moric, flavonoids were also observed in glandular trichomes. The same authors have correlated the degree of complexity of flavonoids and trichomes that occur in the plant. Simple flavonoids structures occur only in the presence of simpler structures, as the degree of complexity of the flavonoids increase the types of trichomes become more complex.

Trichomes play an important role in the maintenance of plant functions. The plants' morphology can help in the identification of the microbe's family, and their functions are dependent on their type and location (Munien et al., 2015). The presence of trichomes in in situ leaves may be related to protection, and the following 2 factors are considered: the presence of substances derived from the secondary metabolism in secretory glands and the number of trichomes present (Jerba et al., 2005).

The secretions accumulated in the glandular trichomes in the in situ and in vitro leaves remained locked, giving a spherical shape to the head of the trichome. This shape is related to the build-up of secondary metabolites (Lima, 2013). While discussing the physiological and ecological significance of the production of terpenic and phenolic compounds in Solanum elaeagnifolium, Christodoulakis (2009) suggested that the production of these compounds in leaves is a defensive response against the stress conditions to which the plant was subjected. In 
terpene metabolism, these alterations may be related to abiotic changes, such as nutrient availability (Behn et al., 2010).

Observation of the dark-grown calluses, regardless of the KIN dose, revealed that they produced higher amounts of nitrogenous (alkaloids), terpenic and phenolic compounds compared to both, calluses grown under light and also in situ and in vitro leaves. In Piper aduncum L. cultivation, the most important compounds were influenced by the environment, indicating that the variations in the production and components of the essential oils of this species depend on the light conditions and may be related to phenotypic characteristics and genetic factors (Pacheco et al., 2016). Victório (2015) emphasizes that light has the capacity to influence the entire secondary metabolism and plant growth. Abiotic elicitors, such as the absence or presence of light, have been used for induction of biosynthesis pathways (Oliveira et al., 2009) and for accumulation and distribution of organic compounds.

In stem segments and in cell suspensions exposed exogenously to $\mathrm{KIN}$, the growth regulator plays important roles in the physiological response in terms of growth and cellular division in the accumulation and retention of tissue metabolites and in the decrease in oxygen consumption. The latter may be related to the inhibition of the glycolytic pathway (Letham, 1967). From this principle, in S. aculeatissimum Jacq. leaf segments were exposed exogenously to KIN to assess physiological behavior. In Panax quinquefolium L., the careful balance of regulators in cultivations was also responsible for the greater increase in metabolite levels compared to adult plants (Zhong et al., 1996).

In the induction of calluses in Carica papaya L., Almeida et al. (2001) assessed the type of explant and the culture medium under a 16 h-photoperiod and in the dark; callus induction was similar under the 2 light conditions. Similarly, callus induction in S. aculeatissimum also showed similar results under the 2 light conditions.

Using different concentrations of KIN, Ikenaga (2000) induced callus in S. aculeatissimum grown in light and dark, and in his study it was possible to observe that it increased the production of steroidal compounds mainly in the dark. Similarly, in this experiment it was clear that in vitro cultivation of callus under different light conditions influenced the activation and increased the production of secondary metabolites, where the best alternative for potentiation occurred in the absence of light according to histochemical responses obtained and compared with the frequencies. By analyzing both conditions, in situ and in vitro sheets, it was possible to observe that there was no difference in the detection of compounds, the two conditions remained the same.

Further studies using biochemical and molecular approaches are needed to understand the responses of the biosynthetic pathways under abiotic elicitation and the regulatory points of such pathways, always aiming to explore plants with the potential for the industrial production of secondary metabolites.

\section{Conclusion}

The production and accumulation of secondary metabolites was higher at dark, independently of KIN doses, which suggests a possibility of decreasing in cost with hormones for in vitro metabolites production.

\section{References}

Adams, S. J., Kuruvilla, G. R., Krishnamurthy, K. V., Nagarajan, M., \& Venkatasubrama-nian, P. (2013). Pharmacognostic and phytochemical studies on Ayurvedic drugs Ativisha and Musta. Revista Brasileira de Farmacognosia, 23, 398-409. https://doi.org/10.1590/S0102-695X2013005000040

Almeida, E. P., Oliveira, R. P., \& Dantas, J. L. L. (2001). Indução e desenvolvimento de calos e embriões somáticos em mamoeiro. Scientia Agricola, 58, 51-54. https://doi.org/10.1590/S0103-90162001000100009

Andrade, E. A., Folguito, D. G., Luz, L. E. C., Paludo, K. S., Farago, P. V., \& Budel, J. M. (2017). Anatomy and histochemistry of leaves and stems of Sapium glandulosum. Revista Brasileira de Farmacognosia. http://doi.org/10.1016/j.bjp.2017.01.001

Anselmo, J. S., \& Lima, R. A. (2014). Identificação de metabólitos secundários no extrato etanólico das folhas de Solanum jamaicense (Solanaceae) e seu potencial fungicida sobre Candida albicans in vitro. Revista Eletrônica de Farmácia, 11, 10. http://doi.org/10.5216/ref.v11i1.27632

Araújo, N. D., Coelho, V. P. D. M., \& Agra, M. D. F. (2010). The pharmacobotanical comparative study of leaves of Solanum crinitum Lam., Solanum gomphodes Dunal and Solanum lycocarpum A. St-Hil, (Solanaceae). Revista Brasileira de Farmacognosia, 20, 666-674. https://doi.org/10.1590/S0102-695X2010005000016

Behn, H., Albert, A., Marx, F., Noga, G., \& Ulbrich, A. (2010). Ultraviolet-B and photosynthetically active radiation interactively affect yield and pattern of monoterpenes in leaves of peppermint (Mentha piperita L. x). Journal of Agricultural and Food Chemistry, 58, 7361-7367. https://doi.org/10.1021/jf9046072 
Bouzon, Z. L., Schmidt, E. C., Almeida, A. C., Yokoya, N. S., Oliveira, M. C., \& Chow, F. (2011). Cytochemical characterization and ultrastructural organization in calluses of the agarophyte Gracilariopsis tenuifrons (Gracilariales, Rhodophyta). Micron, 42, 80-86. https://doi.org/10.1016/j.micron.2010.07.012

Christodoulakis, N. S., Lampri, P., \& Fasseas, C. (2009). Structural and cytochemical investigation of the leaf of silverleaf nightshade (Solanum elaeagnifolium), a drought-resistant alien weed of the Greek flora. Australian Journal of Botany, 57, 432-438. https://doi.org/10.1071/BT08210

David, R., \& Carde, J. P. (1964). Coloration differentielle des inclusions lipidique et terpeniques des pseudophylles du Pin maritime au moyen du reactif Nadi. ComptesRendus de I'Academie des Sciences Paris, 258, 1338-1340.

Franklin, K. A., \& Quail, P. H. (2010). Phytochrome functions in Arabidopsis development. Journal of Experimental Botany, 61(1), 11-24. https://doi.org/10.1093/jxb/erp304

Furr, M., \& Mahlberg, P. G. (1981). Histochemical analyses of laticifers and glandular trichomes in Cannabis sativa. Journal of Natural Products, 44, 153-159. https://doi.org/10.1021/np50014a002

Gabe, M. (1968). Techniques histologiques (p. 427). Paris: Masson.

Ghimire, B. K., Yu, C. Y., \& Chung, I. (2012). Direct shoot organogenesis and assessment of genetic stability in regenerants of Solanum aculeatissimum Jacq. Plant Cell, Tissue and Organ Culture, 108, 455-464. https://doi.org/10.1007/s11240-011-0057-x

Hussain, M. S., Fareed, S., Ansari, S., Rahman, M. A., Ahmad, I. Z., \& Saeed, M. (2012). Current approaches toward production of secondary plant metabolites. Journal of Pharmacy \& Bioallied Sciences, 4, 10-20. https://doi.org/10.4103/0975-7406.92725

Ikenaga, T., Handayani, R., \& Oyama, T. (2000). Steroidal saponin production in callus cultures of Solanum aculeatissimum Jacq. Plant Cell Reports, 19(12), 1240-1244. https://doi.org/10.1007/s002990000250

Jerba, V. F., Rodella, R. A., \& Furtado, E. L. (2005). Relação entre a estrutura foliar de feijoeiro e a pré-infecção por Glomerella cingulataf sp. Phaseoli. Pesquisa Agropecuária Brasileira, 40, 217-223. https://doi.org/ 10.1590/S0100-204X2005000300004

Johansen, D. A. (1940). Plant microtechnique (p. 523). New York: McGraw-Hill Book.

Karuppusamy, S. (2009). A review on trends in production of secondary metabolites from higher plants by in vitro tissue, organ and cell cultures. Journal of Medicinal Plants Research, 3, 1222-1239.

Lau, O. S., \& Deng, X. W. (2010). Plant hormone signaling lightens up: Integrators of light and hormones. Current Opinion in Plant Biology, 13, 571-577. https://doi.org/10.16/j.pbi.2010.07.001

Letham, D. S. (1967). Chemistry and physiology of kinetin-like compounds. Annual Reviewof Plant Physiology, 18, 349-364. https://doi.org/10.1146/annurev.pp.18.060167.002025

Lima, J. F. (2013). Anatomia foliar de Ocimum gratissimum L., com ênfase na caracterização dos tricomas secretores e conteúdo do óleo essencial. Universidade Federal do Recôncavo da Bahia, Cruz das Almas, Bahia.

Maia, V. (1979). Técnica histológica. Atheneu.

Martins, A. R., \& Appezzato-da-Glória, B. (2006). Morfoanatomia dos órgãos vegetativos de Smilax polyantha Griseb. (Smilacaceae). Revista Brasileira de Botânica, 29, 555-567. https://doi.org/10.1590/S0100-8404200 6000400005

Matias, L. J., Simões, M. O. M., Royo, V. A., Ribeiro, L. M., Santos, A. S., \& Fonseca, J. M. S. (2016). Struture and histochemistry of medicinal species of Solanum. Revista Brasileira de Farmacognosia, 26, 147-160. https://doi.org/10.1016/j.bjp.2015.11.002

Munien, P., Naidoo, Y., \& Naidoo, G. (2015). Micromorphology, histochemistry and ultrastructure of the foliar trichomes of Withania somnifera (L.) Dunal (Solanaceae). Planta. 242, 1107-1122. https://doi.org/10.1007/ s00425-015-2341-1

Murashige, T., \& Skoog, F. (1962). A revised medium for rapid growth and bio assays with tobacco tissue cultures. Physiologia Plantarum, 15, 473-479. https://doi.org/10.1111/j.1399-3054.1962.tb08052.x

Nabeta, K. (1993). Solanum aculeatissimum Jacq: in vitro culture and the production of secondary metabolites. In Y. P. S. Bajaj (Ed.), Medical and Aromatic Plants V (pp. 329-341). Springer, Berlin Heidelberg. https://doi.org/10.1007/978-3-642-58062-8_23 
Nogueira, R. C., Paiva, R. P, Porto, J. M. P., Nicioli, P. M., Stein, V. C., Deuner, S., \& Alves, E. (2007). Análise ultra-estrutural de calos embriogênicos de murici-pequeno (Byrsonima intermedia A. Juss.). Revista Brasileira de Biociência, 5, 48-50.

O'Brien, T. P.; \& McCully, M. E. (1981). The study of plant structure: principles and selected methods. Melburne: Termarcarphy Pty.

Oliveira, M. C., Simões, K., \& Braga, M. R. (2009). Substâncias antifúngicas constitutivas e induzidas em folhas e suspensões celulares de Rudgea jasminoides (Cham.) Müll. Arg. (Rubiaceae). Revista Brasileira de Botânica, 32, 509-519. https://doi.org/10.1590/S0100-84042009000300010

Oliveira, R. C. de, Vasconcelos, F. S. C., Bastos, A. V. S., Vasconcelos, J. M., \& Rodrigues, A. A. (2015). Anatomical and histochemical analysis of vegetative organs of Vernonia ferruginea less. (Asteraceae). African Journal of Biotechnology, 14, 2734-2739. https://doi.org/10.5897/AJB2015.14934

Pacheco, F. V., Avelar, R. P., Alvarenga, I. C. A., Bertolucci, S. K. V., Alvarenga, A. A., \& Pinto, J. E. B. P. (2016). Essential oil of monkey-peper (Piper aduncum L.) cultivated under different light environments. Industrial Crops and Products, 86, 251-257. https://doi.org/10.1016/j.indcrop.2016.03.016

Picoli, E. A. T., Isaias, R. M. S., Ventrella, M. C., \& Miranda, R. M. (2013). Anatomy, histochemistry and micromorphology of leaves of Solanum granuloso-leprosum dunal Anatomia, histoquímica e micromorfologia de folhas de Solanum granuloso-leprosum dunal. Bioscience Journal, 29.

Reina-Pinto, J. J., \& Yephremov, A. (2009). Surface lipids and plant defenses. Plant Physiology and Biochemistry, 47, 540-549. https://doi.org/10.1016/j.plaphy.2009.01.004

Rossato, A. E., Pierini, M. M., Amaral, P. A., Santos, R. R., \& Citadini, V. (2012). Fitoterapia Racional: Aspectos Taxonômicos, Agroecológicos, Etnobotânicos e Terapêuticos. Diretoria da Imprensa Oficial e Editora de Santa Catarina, Florianópolis.

Santos, A. V., Defaveri, A. C. A., Bizzo, H. R., San Gil, R. A. D. S., \& Sato, A. (2013). In vitro propagation, histochemistry, and analysis of essential oil from conventionally propagated and in vitro-propagated plants of Varronia curassavica Jacq. In Vitro Cellular \& Developmental Biology-Plant, 49, 405-413. https://doi.org/10.1007/s11627-013-9528-6

Santos, M. M., Nunes, M. G. S., \& Martins, R. D. (2012). Uso empírico de plantas medicinais para tratamento de diabetes. Revista Brasileira de Plantas Medicinais, 14, 327-334. https://doi.org/10.1590/S1516-05722012 000200012

Silva, T. M. S., Carvalho, M. G. de, Braz-Filho, R., \& Agra, M. de F. (2003). Ocorrência de flavonas, flavonóis e seus glicosídeos em espécies do gênero Solanum (Solanaceae). Quimica Nova, 26, 517-522. https://doi.org/ $10.1590 / \mathrm{S} 0100-40422003000400014$

Toledo Picoli, E. A., dos Santos Isaías, R. M., Ventrella, M. C., \& de Miranda, R. M. (2013). Anatomy, histochemistry and micromorphology of leaves of Solanum granuloso-leprosum Dunal. Bioscience Journal, 29, 655-666.

Vasconcelos, J. M., Vasconcelos Filho, S. C., Sales, J. F., \& Silva, F. G. (2013). Anatomical and histochemical characterization of Strychnos pseudoquina (A. ST. HIL.) leaves. Global Science and Technology, 6. https://doi.org/10.14688/1984-3801.V06N02A14

Victório, C. P., Leal-Costa, M. V., Tavares, E. S., Kuster, R. M., \& Lage, C. L. S. (2015). Light spectral affect the morphoanatomical and chemicals features of clonal Phyllantus tenellus Roxb. grown in vitro. Journal of Medicinal Plants Research, 9, 111-121. https://doi.org/10.5897/JMPR2014.5410

Yendo, A. C., de Costa, F., Gosmann, G., \& Fett-Neto, A. G. (2010). Production of plant bioactive triterpenoidsaponins: Elicitation strategies and target genes to improve yields. Molecular Biotechnology, 46, 94-104. https://doi.org/10,1007/s12033-010-9257-6

Zhong, J. J., Bai, Y., \& Wang, S. J. (1996). Effects of plant growth on cell growth and ginsenosidesaponin production by suspension cultures of Panax quinquefolium. Journal of Biotechnology, 45, 227-234. https://doi.org/10.1016/0168-1656(95)00170-0 


\section{Abbreviations}

2,4-D: 2,4-dichlorophenoxyacetic acid;

KIN: Kinetin;

MS: Murashige and Skoog;

NADI: $\alpha$-Naphthol and dimethyl-p-phenylenediamine;

PAS: Periodic acid/Schiff stain;

XP: Xylidine Ponceau.

\section{Copyrights}

Copyright for this article is retained by the author(s), with first publication rights granted to the journal.

This is an open-access article distributed under the terms and conditions of the Creative Commons Attribution license (http://creativecommons.org/licenses/by/4.0/). 